\title{
IMPORTANCE OF HAND GERM CONTAMINATION IN HEALTH-CARE WORKERS AS POSSIBLE CARRIERS OF NOSOCOMIAL INFECTIONS
}

Mónica NOGUERAS(1), Nicolás MARINSALTA(1), Mauricio ROUSSELL(1) \& Rodolfo NOTARIO(1)

\begin{abstract}
SUMMARY
The importance of hands in the transmission of nosocomial infection has been world wide admitted. However, it is difficult to induce this behavior in health-care workers. The aim of the present work was to point out the importance of hand bacteria colonization, the influence of hand washing and of patient physical examination. One hundred health-care workers were randomly divided in two groups: Group A without hand washing previous to patient physical examination or handling (PPE); group B with hand washing previous to PPE. Direct fingerprint samples in Columbia agar before and after PPE were obtained. The colonies were counted and identified by conventional techniques, and antibiograms according to NCCLS were performed. Before PPE group A participants showed a high number of bacteria regarding group B participants (73.9 Vs 20.7; p < 0.001); 44 out of 50 participants were carriers of potentially pathogen bacteria. No group B participants were carriers of potential pathogen bacteria before PPE. The latter group showed an increase in number of bacteria after PPE (20.7 CFU (before) Vs 115.9 CFU (after); $\mathrm{p}<0.001$ ). Sixteen group B participants were contaminated after PPE with potential pathogens such as S. aureus (50\% of them meticillin resistant); Escherichia coli, Pseudomonas aeruginosa and Enterococcus faecalis, half of them multiresistant. We can conclude on the importance of these results to implement educational programs and to provide the health-care workers with the proper commodities to fulfill this practice.
\end{abstract}

KEYWORDS: Hand washing; Hospital infection; Colonization.

\section{INTRODUCTION}

Nosocomial infection is a frequent problem affecting hospitalized patients, increasing hospitalization time and mortality ${ }^{3,11,17}$. The importance of hands in the transmission of hospital infections is worldwide accepted ${ }^{6,13}$. However, it is difficult to include hand washing (HW) as routine behavior in health-care workers since microorganisms are invisible or there are no adequate elements to carry out this practice ${ }^{8}$.

Health-workers hands by themselves, or after contact with patients, increase the risk of virus and bacteria transmission that are sometimes resistant to antimicrobial agents (AMA) ${ }^{6}$. This is a two-way hazard that could be noxious to both patients and health-care workers, and which depends on the nature and frequency of contact with infectious materials, inoculum and prevalence of susceptible patients ${ }^{6}$.

Despite the knowledge of the importance of this fact by health-care workers $(\mathrm{HCW})$ they do not practice hand washing ${ }^{5,8,15}$ which is more neglected by physicians than nurses ${ }^{4,13}$.

The aim of the present work was to point out the hand bacterial colonization, the hand washing influence and the modifications regarding microorganism transportation after a patient physical examination.

\section{MATERIAL AND METHODS}

Population. One hundred health-care workers were recruited developing their tasks in five health centers in different areas of Rosario city. After the physical examination the participants were invited to answer a questionnaire that was part of a medical investigation, clearly stating that this information was confidential and anonymous according to research ethic guidelines ${ }^{14}$. According to their answers, the population was divided in two groups keeping the same proportion of physicians, medical students and nurses. Group A: Health-care workers that submitted to the questionnaire admitted no hand washing practice according to established recommendations ${ }^{4}$ before patient examination or handling (PPE). Group B: Health-care workers practicing hand washing according to established recommendations.

Microbiology. Direct finger-print samples ${ }^{16}$ in agar Columbia before and after hospitalized PPE, were obtained. The agar plates were incubated at $37{ }^{\circ} \mathrm{C}$ in a $10 \% \mathrm{CO}_{2}$ during 24 to 48 hours. The colonies were counted and identified by conventional techniques. Susceptibility test according to NCCLS recommendations were performed ${ }^{12}$. The strains resistant to 6 or more antimicrobial agents were considered as multiresistant. Micrococcus spp, Staphylococcus coagulase negative, Corynebacterium 
spp and Bacillus spp were considered as skin saprophytes. The remaining agents were considered potential pathogens.

Statistical analysis. Colony forming units (CFU) mean counts, in agar plates were compared by the proportion hypothesis test (Student's $\mathrm{t}$ test).

\section{RESULTS}

Before patient physical examination, group A health-care workers that had not practiced previous hand washing showed a number of $\mathrm{CFU}$ significantly higher than group B participants that had practiced previous hand washing $(\mathrm{p}<0.001)$ (Table 1). Forty four group A HCW presented potentially pathogenic bacteria before patient physical examination, 20 out of 40 with gram negative bacilli and 18 out of 40 with $S$. aureus. In contrast, in group B before physical examination the participants were only saprophyte carriers.

Even if group A participants showed a CFU mean higher after the patient physical examination (73.9 vs 99.7) the difference was not significant (Table 1).

Group B participants presented a remarkable bacteria count increase after patient physical examination, i.e. 20.7 before PPE to 115.9 after PPE $(\mathrm{p}<0.001)$. Sixteen participants of the group B $(32 \%)$ acquired potential pathogenic bacteria after PPE ( 8 to $80 \mathrm{CFU} / \mathrm{HW}$ ). In fact, one participant acquired Escherichia coli, another one Pseudomonas aeruginosa, and a third Enterococcus faecalis, while 13 participants were contaminated with S. aureus after PPE (Table 2). Almost 50\% of the latter participants were contaminated with meticillin resistant $S$. aureus (MRSA).

Six gram negative bacilli strains out of 20 microorganisms occurring after PPE in both groups were multiresistant, $3 P$. aeruginosa strains isolated were piperacillin and aminoglycoside antibiotic resistant, and one out of three E. faecalis strains were resistant to high levels of gentamicin, streptomycin and kanamycin.

\section{Table 1}

Comparison of CFU mean in health-care workers, before and after patient physical examination or handling in both groups under study. Group A without previous hand washing according to recommendations ${ }^{4}$, and group B with previous hand washing

\begin{tabular}{clll}
\hline Group & $\begin{array}{l}\text { Before } \\
\text { PPE }(*)\end{array}$ & $\begin{array}{l}\text { After } \\
\text { PPE }\end{array}$ & \\
\hline A & 73.9 & 99.7 & $\mathrm{t}=1.82 \mathrm{p}>0.05 \mathrm{NS}$ \\
B & 20.7 & 115.9 & $\mathrm{t}=9.81 \mathrm{p}<0.001$ \\
& & & \\
& $\mathrm{t}=5.75$ & $\mathrm{t}=1.125$ & \\
& $\mathrm{p}<0.001$ & $\mathrm{p}>0.05$ & $\mathrm{NS}$ \\
\hline
\end{tabular}

* Patient physical examination or handling

Table 2

Bacteria isolated from health care workers. Group A: no hand washing according to recommendations ${ }^{4}$; group B: hand washing both before and after patient physical examination or handling

\begin{tabular}{|c|c|c|c|c|c|c|}
\hline \multirow{3}{*}{ Bacteria } & \multicolumn{6}{|c|}{ Group (1) } \\
\hline & \multicolumn{3}{|c|}{$A(N=50)$} & \multicolumn{3}{|c|}{$\mathrm{B}(\mathrm{N}=50)$} \\
\hline & Before & After & Total & Before & After & Total \\
\hline Micrococcus spp & 9 & 9 & 10 & 12 & 14 & 18 \\
\hline Bacillus spp & 21 & 22 & 26 & 26 & 25 & 34 \\
\hline Corynebacterium spp & 6 & 6 & 9 & 1 & 6 & 6 \\
\hline Staphylococcus coag - & 49 & 50 & 50 & 48 & 43 & 49 \\
\hline S. aureus MS (2) & 10 & 10 & 12 & 0 & 7 & 7 \\
\hline S. aureus MR (2) & 4 & 3 & 6 & 0 & 6 & 6 \\
\hline Enterococcus faecalis & 6 & 6 & 9 & 1 & 6 & 6 \\
\hline Klebsiella pneumoniae & 1 & 1 & 1 & 0 & 0 & 0 \\
\hline Escherichia coli & 0 & 0 & 0 & 0 & 1 & 1 \\
\hline Pseudomonas aeruginosa & 3 & 2 & 3 & 0 & 1 & 1 \\
\hline P. picketti & 1 & 1 & 1 & 0 & 0 & 0 \\
\hline P. paucimobilis & 1 & 1 & 2 & 0 & 0 & 0 \\
\hline Acinetobacter baumannii & 2 & 4 & 5 & 0 & 0 & 0 \\
\hline A. lwoffi & 0 & 1 & 1 & 0 & 0 & 0 \\
\hline Alcaligenes spp & 1 & 1 & 1 & 0 & 0 & 0 \\
\hline A. denitrificans & 1 & 1 & 1 & 0 & 0 & 0 \\
\hline WK group II F (CDC) & 1 & 1 & 1 & 0 & 0 & 0 \\
\hline IV C II (CDC) & 0 & 1 & 1 & 0 & 0 & 0 \\
\hline
\end{tabular}

(1) Totals including health-care workers in whom bacteria were isolated before and after patient physical examination or both; (2) MS = meticillin sensitive; MR = meticillin resistant 


\section{DISCUSSION}

Hand washing is the most important clinical procedure ${ }^{4}$. With this practice ROSSOFF et al. were able to diminish the bacteria content in the finger tips from 84 to $2 \mathrm{CFU}^{16}$. In a survey carried out in Guatemala the changes in decontamination procedures diminished the nosocomial infection from 33 to 16 per cent.

Although the importance of handwashing is routinely acknowledged, a religious application of this practice still does not exist ${ }^{15}$.

Hand washing either with soap and water or with antiseptic agents diminishes contamination ${ }^{7}$. Introduction of easily accessible dispensers with an alcohol-based waterless handwashing antiseptic led to significantly higher handwashing rates among health care workers ${ }^{2}$.

The fingerprint methodology to obtain direct finger tips samples on agar plates is a simple and efficient technique 9

The group A HCWs that did not wash their hand showed an important bacterial content in their hands before PPE, which did not increase significantly after PPE, probably due to the incapacity to host a greater bacterial content. Many of these microorganisms are potentially pathogenic. In contrast, group B participants showed a remarkably lower bacteria content in accordance with ROSSOFF et $a l^{16}$.

No group B HCWs presented potential pathogenic germs before the PPE. On the contrary, after PPE, almost one third of them acquired potentially pathogenic bacteria such as $S$. aureus, E. coli, P. aeruginosa and E. faecalis, many of them resistant to antimicrobial agents. Consequently, the hand washing before and after PPE, as well as glove use is highly recommended ${ }^{10,16}$. The E. faecalis presence has been considered as an enteric bacteria contamination indicator?

Thirty two per cent of hospitalized patients in digestive surgery intensive care unit were contaminated after 24 days with 1,2 or even 3 simultaneous strains of a high extended beta lactamase producing bacteria, such as E. coli, Klebsiella pneumoniae and E. aerogenes ${ }^{18}$. Two outbreaks due to multiresistant Acinetobacter spp were very serious with a high mortality ${ }^{3,11}$. Five Acinetobacter baumannii strains and one Alcaligenes denitrificans strain isolated after PPE were multiresistant.

Educational programs to implement a generalized practice of hand washing should be insistently put to work ${ }^{5,13}$. The evidenced hand bacterial contamination pointed out in the present work will be used to change the health-care workers behavior and try to obtain the provision of soap, antiseptic agents, disposable dry towels and gloves in all the areas in order to obtain a routine practice.

\section{RESUMO}

Importância da contaminação das mãos por germes, em trabalhadores da saúde, como possíveis transmissores de infecções hospitalares

A importância das mãos na transmissão de infecções hospitalares é aceita mundialmente. Todavia, é difícil introduzir este procedimento entre os trabalhadores da saúde. Este trabalho pretendeu evidenciar a colonização das mãos por bactérias e a influência da lavagem de mãos e o exame físico dos pacientes. 100 profisionais de saúde foram divididos, ao acaso em dois grupos: A - sem lavagem de mãos antes do exame físico ou manejo dos pacientes (PPE); B - com lavagem prévia das mãos antes do PPE. Foram obtidas amostras de impressões digitais em agar Columbia antes e depois do PPE. As colônias foram contadas e identificadas por técnicas convencionais e antibiogramas de acordo com NCCLS. Antes do PPE os participantes do grupo A apresentaram elevado número de bactérias em relação ao grupo B (73.9 vs. 20.7; p < 0.001); 44 dos 50 participantes eram portadores potenciais de bactérias patogênicas. Nenhum participante do grupo B era portador de bactéria potencialmente patogênica antes do PPE. Este grupo mostrou um aumento no número de bactérias depois do PPE (20.7 UFC antes vs. 115.9 UFC depois; $\mathrm{p}<0.001)$. 16 participantes do grupo B foram contaminados, depois do PPE, com patógenos potenciais tais como $S$. aureus (50\% dos quais eram resistentes à meticilina), Escherichia coli, Pseudomonas aeruginosa e Enterococcus faecalis, metade dos quais, multiresistentes. Podemos concluir sobre a importância destes resultados para implementar programas educacionais e para prover os trabalhadores da saúde com facilidades para o adequado cumprimento desta prática.

\section{REFERENCES}

1. BERG, D.E.; HERSHOW R.C.; RAMIREZ, C.A. \& WEINSTEIN, R.A. - Control of nosocomial infections in an intensive care unit in Guatemala city. Clin. infect. Dis., 21: 588-593, 1995.

2. BISCHOFF, W.E.; REYNOLDS, T.M.; SESSLER, C.N.; EDMOND, M.B. \& WENZEL, R.P. - Handwashing compliance by health care workers: the impact of introducing an accessible, alcohol-based hand antiseptic. Arch. intern. Med., 160: 1017-1021, 2000.

3. CROWE, M.; TOWNER, K.J. \& HUMPHREYS, H. - Clinical and epidemiological features of an outbreak of Acinetobacter infection in an intensive therapy unit. $\mathbf{J}$. med. Microbiol., 43: 55-62, 1995.

4. DORSEY, S.T.; CYDULKA, R.K. \& EMERMAN, C.L. - Is handwashing teachable?: failure to improve handwashing behavior in an urban emergency department. Acad. emerg. Med., 3: 360-365, 1996.

5. ELLIOTT, P.R. - Handwashing practice in nurse education. Prof. Nurse, 11: 357-360, 1996.

6. FAY, M.F. - Hand protection against viral pathogens. Brit. J. Theatre Nursing, 6: 5-9, 1996.

7. FUKADA, T.; TACHIBANA, C.; TSUKAZAKI, Y. et al. - Bacterial contamination of anesthesiologists' hands and the efficacy of handwashing. Masui, 45: 1026-1030, 1996

8. GOULD, D. - Hand decontamination: nurses opinions and practices. Nursing Times, 91: 42-45, 1995.

9. KALTENTHALER, E.C. \& PINFOLD, J.V. - Microbiological method for assessing handwashing practice in hygiene behaviour studies. J. trop. Med. Hyg., 98: 101106, 1995.

10. LUND, S.; JACKSON, J.; LEGGETT, J. et al. - Reality of glove use and handwashing in a community hospital. Amer. J. infect. Control, 22: 352-357, 1994.

11. LYYTIKAINEN, O.; KOLJALG, S.; HARMA, M. \& VUOPIO-VARKILA, J. - Outbreak caused by two multi resistant Acinetobacter baumannii clones in a burns unit: emergence of resistance to imipenem. J. Hosp. Infect., 31: 41-54, 1995.

12. MURRAY, P.R. - Manual of clinical Microbiology. Washington, ASM Press, 1995. 
NOGUERAS, M.; MARINSALTA, N.; ROUSSELL, M. \& NOTARIO, R. - Importance of hand germ contamination in health-care workers as possible carriers of nosocomial infections. Rev. Inst. Med. trop. S. Paulo, 43(3):149-152, 2001.

13. NYSTROM, B. - Impact of handwashing on mortality in intensive care: examination of the evidence. Infect. Control Hosp. Epidem., 15: 435-436, 1994.

14. ORGANIZACIÓN PANAMERICANA DE LA SALUD - Normas éticas internacionales para las investigaciones biomédicas con sujetos humanos. Washington, OPS, 1996. (Publicación científica No. 563).

15. PARKER, L.J. - Importance of handwashing in the prevention of cross-infection. Brit. J. Nurs., 8: 716-720, 1999.
16. ROSSOFF, L.J.; BORENSTEIN, M. \& ISENBERG, H.D. - Is hand washing really needed in an intensive care unit? Crit. Care Med., 23: 1211-1216, 1995

17. SAXEN, H.; VIRTANEN, M.; CARLSON, P. et al. - Neonatal Candida parapsilosis outbreak with a high case fatality rate. Pediat.. infect. Dis. J., 14: 776-781, 1995.

18. SOULIER, A.; BARBUT, F.; OLLIVIER, J.M.; PETIT, J.C. \& LIENHART, A. - Decreased transmission of Enterobacteriaceae with extended spectrum beta-lactamases in an intensive care unit by nursing reorganization. J. Hosp. Infect., 31: 89-97, 1995.

Received: 28 April 2000

Accepted: 16 October 2000 